\title{
Long-term goals in the treatment of chronic graft-versus-host disease after matched allogeneic hematopoietic stem cell transplantation
}

\author{
Ivan S. Moiseev, Anna A. Dotsenko, Anna G. Smirnova, Yulia Yu. Vlasova, Elena V. Morozova, Sergey N. Bondarenko, \\ Boris V. Afanasyev \\ RM Gorbacheva Research Institute of Pediatric Oncology, Hematology and Transplantation, Pavlov University, St. Petersburg, \\ Russia
}

Ivan S. Moiseev, PhD, MD. RM Gorbacheva Research Institute of Pediatric Oncology, Hematology and Transplantation, Pavlov University, L.Tolstoy St. 6-8, 197022, St. Petersburg, Russia
Phone: +7(812) 338 6259, +7 (921) 7961951

Fax: +7(812) 3386263

E-mail: moisiv@mail.ru

Citation: Moiseev IS, Dotsenko AA, Smirnova AG et al. Long-term goals in the treatment of chronic graft-versus-host disease after matched allogeneic hematopoietic stem cell transplantation. Cell Ther Transplant 2020; 9(4): 29-36.

\section{Summary}

Chronic graft-versus-host disease (cGvHD) is a common complication of allogeneic hematopoietic stem cell transplantation. Its incidence varies from $10 \%$ to $80 \%$ according to the type of prophylaxis, type of the donor and other risk factors. Although cGvHD is associated with reduced risk of relapse, the persistence of clinical signs is associated with long-term mortality, morbidity and disability. Despite there are clear endpoints for the clinical trials of novel agents, the choices in clinical practice should involve long-term goals like in all autoimmune disease. So far, there is no consensus on these goals. Analyzing the results of cGvHD therapy in the large single-center cohort of patients we tried to focus on predictors of long-term prognosis and their association with therapy.

\section{Patients and methods}

The study included 182 patients with moderate and severe $c G v H D$. The majority of patients were allografted for malignant diseases and $49 \%$ had severe cGvHD, $51 \%$ - moderate disease. Median follow up time was 52 months. Beyond the first line $39.56 \%$ of patients required additional treatment.

\section{Results}

At five years the cumulative incidence of complete responses was $16.9 \%$ (95\% CI $10.5-24.7 \%$ ) and immunosuppressive therapy (IST) discontinuation without
GvHD flare was 51.2\% (95\% CI 40.0-61.2\%). The major predictors of IST discontinuation were overall severity of cGvHD (HR 0.45, 95\%CI 0.25-0.84, p=0.0049) and female donor for male recipient (HR 0.33, 95\%CI 0.25 $0.81, \mathrm{p}=0.0370$ ). The analysis of non-relapse mortality (NRM) demonstrated that discontinuation of IST was the major predictor ( $2 \%$ vs $42 \%$, HR 0.03 , 95\%CI 0.01 $0.15, p=0.0005)$. At the end of the follow up patients with complete response discontinued IST in $91 \%$ of cases, with mild cGvHD in $53 \%$ of cases, with moderate in $24 \%$ of cases and with severe in $2 \%$ of cases. The other significant factors for NRM were steroid-free starting therapy (HR 0.25, 95\%CI 0.08-0.58, $\mathrm{p}=0.0035$ ) and early use of second-line therapy (HR 0.49, 95\%CI 0.25-0.96, $\mathrm{p}=0.0322$ ). In conclusion, the study demonstrated that discontinuation of systemic IST therapy without the flare of cGvHD should be the goal of therapy. Also the study creates a rationale for randomized studies of novel second-line options not with but against steroids in the first line.

\section{Keywords}

Chronic graft-versus-host disease, therapy, long-term outcomes, goals of therapy . 


\section{Introduction}

Chronic graft-versus-host disease (cGvHD) is a complication of allogeneic hematopoietic stem cell transplantation (allo-HSCT), which is associated both with long-term mortality and significant disability in long-term survivors. Its incidence varies from $10 \%$ to $80 \%$ according to the type of prophylaxis, type of the donor and several other risk factors [1-4]. Although cGvHD is associated with reduced risk of relapse and improved survival in the majority of malignant diseases [5], the persistence of clinical signs is associated with long-term mortality due to cardiovascular disease, infections and secondary malignancies [6]. Also cGvHD is the major cause of decline in the quality of life (QoL), social and professional disability. Gastrointestinal, joint and kidney problems are the main drivers of QoL decline [7-9].

The early studies of cGvHD treatment demonstrated a superiority of steroids over other agents in the treatment of cGvHD in terms of survival $[10,11]$. However all subsequent attempts to improve response rate with augmented immunosuppression were not successful. Addition of thalidomide and mycofenolate mofetil resulted in higher frequency of adverse events and infection-related mortality $[12,13]$. The only combination with some benefit in terms of steroid sparing was the combination of steroids and cyclosporine A (CsA), which demonstrated comparable response rate and duration of immunosuppression, however the cumulative dose of steroids was less in the combination arm, which resulted in the reduced frequency of femur aseptic necrosis [14]. The failure of these clinical trials to demonstrate improved response rate lead to the shift in the concept of cGvHD treatment. Currenly it is considered that immunosuppressive therapy (IST) does not induce tolerance, but rather alleviates target organ damage before the tolerance between donor and recipient cells occur. This understanding creates a dissonance between endpoints from the clinical studies and the real clinical practice where the formal response criteria, like decrease in the severity score or improved 2-minute walk test results, does not necessarily correlate with long-term prognosis.

While several studies focus on the clinical features of cGvHD that are associated with adverse prognosis $[15,16]$, few focus on the prognosis according to the response to treatment. Now we have novel effective treatments for steroid-refractory disease, which could be steroid-sparing and facilitate better clinical responses $[17,18]$. Thus it is important to define the goals of therapy for cGvHD. In this single center study we did not evaluate the outcomes of certain treatment modalities for chronic GvHD but rather focused on IST discontinuation, complete response of cGvHD and survival. For this purpose we included only patients who have long-term follow up after onset of cGvHD. As the first line of therapy $62 \%$ of patients received prednisone $1 \mathrm{mg} / \mathrm{kg}$ daily in combination with calcineurin inhibitor (CNI), $22 \%$ received $\mathrm{CNI}$ as the monotherapy, $16 \%$ received monotherapy with a second line treatments.

\section{Patients and methods}

\section{Patients and transplantation procedures}

Two hundred and nine patients transplanted in 2006-2017 in Pavlov First Saint Petersburg State Medical University were included in the study. The inclusion criteria were moderate or severe disease according to National Institute of Health (NIH) 2015 criteria [19], administration of systemic treatment for cGvHD, transplantation from 9-10/10 HLAmatched related or unrelated donor. All patients signed informed consent for the use of their medical data in research purposes. Two thirds of patients had either acute myeloblastic leukemia or acute lymphoblastic leukemia, $49 \%$ had severe $\mathrm{cGvHD}$, 51\% - moderate. Median time from HSCT to cGvHD onset was 166 days. Twenty three percent received GvHD prophylaxis with post-transplantation cyclophosphamide (PTCY) and the rest - conventional prophylaxis with calcineurin inhibitor and antimetabolite. Median follow up time after the onset of cGvHD was 52 months. More than $56 \%$ had three or more organ involvement (Table 1).

\section{Clinical definitions}

Time to disease relapse incidence (RI), complete response (CR), non-relapse mortality (NRM), overall survival (OS) and event-free survival (EFS), were defined as the time from cGvHD onset to the event. RI and NRM were considered a competing risk events. RI and CR were also considered competing risks. cGvHD severity was evaluated using NIH 2015 criteria [19], while response using $2006 \mathrm{NIH}$ criteria [20]. Complete response was defined as absence of cGvHD clinical signs with IST discontinued. Partial response (PR) was defined as decrease in the total NIH score without increase in each individual organ score.

\section{Statistical analysis}

Non-parametric analysis included Chi-square test, Mann-Whitney test according to the type of data. The survival distributions for OS, EFS, were calculated using Kaplan-Meier methodology. The comparisons were made using the log-rank test. Cumulative incidence analysis with competing risks RI, NRM, CR was performed using Gray test. Relapse and NRM were accounted as competing risks as well as RI and CR. Fine and Grey regression was used for the multivariate analysis of cumulative incidences. Factors used for multivariate correction had at least $\mathrm{p}=0.10$ significance in the univariate analysis.

\section{Results}

As the first line of therapy $62 \%$ of patients received prednisone $1 \mathrm{mg} / \mathrm{kg}$ daily in combination with calcineurin inhibitor (CNI), 22\% received CNI as the monotherapy, 16\% received monotherapy with a second line treatment (pharmacological or extracorporeal photopheresis without steroids. Beyond the first line $39.56 \%$ of patients required additional treatment. The most frequent options were ECP, IL-2, JAK inhibitors, BTK inhibitors, tyrosine-kinase inhibitors (TKI).

At five years, the cumulative incidence of CR was $16.9 \%$ (95\% CI 10.5-24.7\%). The proportion of patients with CR was $18.68 \%$. However the cumulative incidence of IST discontinuation without GVHD flare was higher - 51.2\% (95\% CI 40.0-61.2\%), and close to the proportion of patients with $\mathrm{CR}$ and mild chronic GvHD manifestations after treatment (44.5\%). The competing risk of relapse was $25.4 \%$ (95\% CI 18.6-32.8\%) (Fig. 1). 
Table 1.

\begin{tabular}{|c|c|}
\hline Clinical characteristic & \\
\hline Number of patients & 182 \\
\hline Gender, m/f & $50.55 \% / 49.45 \%$ \\
\hline Age, years, median (range) & $33(18-66)$ \\
\hline Median day (range) of cGuHD onset & $163(74-1424)$ \\
\hline $\begin{array}{l}\text { Diagnosis } \\
\text { AML } \\
\text { ALL } \\
\text { CML } \\
\text { MDS } \\
\text { Lymphomas } \\
\text { AA } \\
\text { Other diseases }\end{array}$ & $\begin{array}{l}46.15 \% \\
26.37 \% \\
8.24 \% \\
8.24 \% \\
5.50 \% \\
1.65 \% \\
3.85 \% \\
\end{array}$ \\
\hline $\begin{array}{l}\text { Matched related } \\
\text { Matched unrelated }\end{array}$ & $\begin{array}{l}24,88 \% \\
73.63 \% \\
\end{array}$ \\
\hline $\begin{array}{l}\text { Graft source } \\
\text { Bone marrow } \\
\text { PBSC }\end{array}$ & $\begin{array}{l}28.57 \% \\
71.43 \% \\
\end{array}$ \\
\hline $\begin{array}{l}\text { Conditioning regimen } \\
\text { MAC } \\
\text { RIC }\end{array}$ & $\begin{array}{l}29.12 \% \\
70.88 \% \\
\end{array}$ \\
\hline "Salvage" patients & $15.38 \%$ \\
\hline $\begin{array}{l}\text { Allo-HSCT number } \\
\text { First } \\
\text { Subsequent }\end{array}$ & $\begin{array}{l}94.48 \% \\
5.52 \% \\
\end{array}$ \\
\hline $\begin{array}{l}\text { HLA-matching } \\
10 / 10 \\
9 / 10\end{array}$ & $\begin{array}{l}84.07 \% \\
15.93 \%\end{array}$ \\
\hline Female donor for male recipient & $19.89 \%$ \\
\hline $\begin{array}{l}\text { GVHD prophylaxis } \\
\text { PTCy } \\
\text { Classical }\end{array}$ & $\begin{array}{l}33.52 \% \\
66.48 \%\end{array}$ \\
\hline $\begin{array}{l}\text { Calcineurin inhibitor in prophylaxis } \\
\text { Cyclosporine A } \\
\text { Tacrolimus } \\
\text { None }\end{array}$ & $\begin{array}{l}21.55 \% \\
66.85 \% \\
11.60 \%\end{array}$ \\
\hline $\begin{array}{l}\text { Third GvHD prophylaxis agent } \\
\text { Methotrexate } \\
\text { MMF } \\
\text { None }\end{array}$ & $\begin{array}{l}41.44 \% \\
46.11 \% \\
12.45 \% \\
\end{array}$ \\
\hline Previous acute GvHD I-IV & $74.18 \%$ \\
\hline Previous acute GvHD III-IV & $25.27 \%$ \\
\hline $\begin{array}{l}\text { NIH severity score } \\
\text { Moderate } \\
\text { Severe }\end{array}$ & $\begin{array}{l}43.41 \% \\
56.59 \%\end{array}$ \\
\hline $\begin{array}{l}\text { Organs involved } \\
\text { Skin } \\
\text { Mucosa } \\
\text { Eyes } \\
\text { Gastrointestinal } \\
\text { Liver } \\
\text { Lungs } \\
\text { Joints } \\
\text { Genitalia }\end{array}$ & $\begin{array}{l}83.52 \% \\
60.44 \% \\
48.07 \% \\
41.76 \% \\
40.11 \% \\
19.89 \% \\
13.74 \% \\
9.34 \%\end{array}$ \\
\hline
\end{tabular}

A $\square$ None $\square$ Mild $\square$ Moderate $\square$ Severe
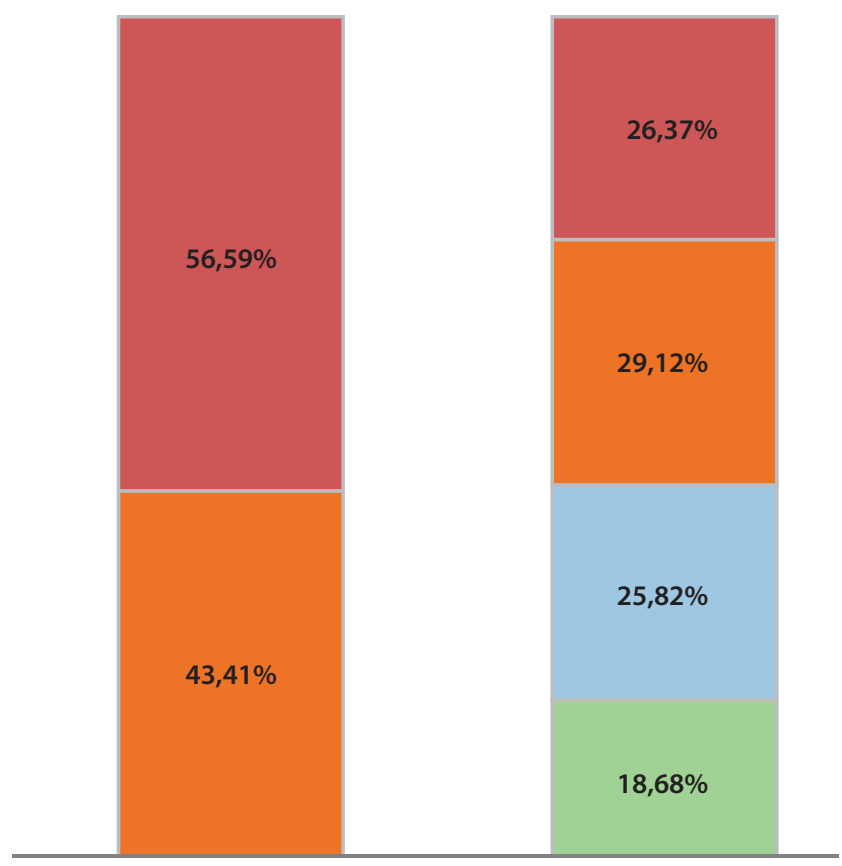

Before treatment

After treatment

\section{B}

\section{Cumulative incidence of CR and IST discontinued}

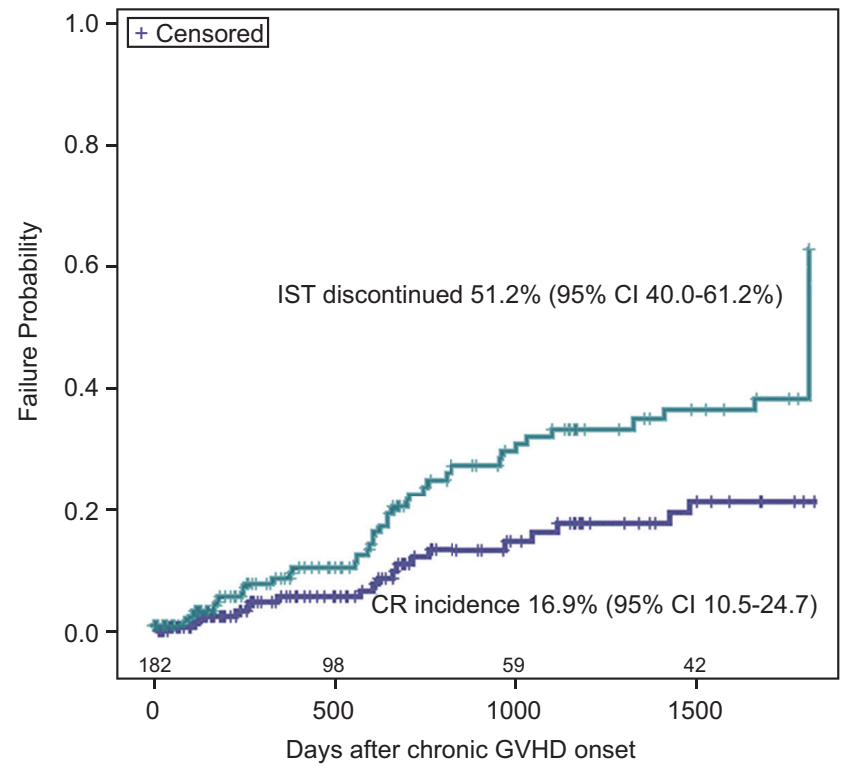

Figure 1. (A) Initial severity of cGvHD before treatment and at last follow up. (B) Cumulative incidence of complete remission and immunosuppression (IST) discontinuation. Relapse was accounted as competing risk 
In the multivariate analysis there was only one significant predictor of CR - severe form of chronic GvHD comparing to the moderate disease (HR 0.26, 95\%CI 0.08-0.728, $\mathrm{p}=0.0194)$. The other factors significant in the univariate analysis like type of initial treatment (HR 0.84, 95\%CI 0.44$1.46, \mathrm{p}=0.5154$ ), type of GvHD prophylaxis (HR 0.95, 95\% CI $0.34-2.48, \mathrm{p}=0.9122$ ), previous acute GvHD grade 3-4 (HR $0.82,95 \% \mathrm{CI} 0.28-2.40, \mathrm{p}=0.82)$ and number of organs involved (HR 0.77, 95\%CI 0.52-1.08, $\mathrm{p}=0.1751$ ) had no impact on CR cumulative incidence.

In the multivariate analysis of IST discontinuation, the statistical significance was observed for overall severity of cGvHD (HR 0.45, 95\%CI 0.25-0.84, $\mathrm{p}=0.0049$ ) and female donor for male recipient (HR $0.33,95 \%$ CI $0.25-0.81, \mathrm{p}=0.0370$ ). The other factors like type of the donor (HR 0.70, 95\%CI 0.37-1.38, $\mathrm{p}=0.2909$ ), previous severe acute GvHD (HR 0.96, 95\%CI 0.49-1.82, $\mathrm{p}=0.9379)$, type of initial GvHD treatment (HR 0.93, 95\%CI 0.63-1.33, p=0.7021), GI involvement (HR $0.76,95 \% \mathrm{CI} 0.53-1.04, \mathrm{p}=0.1223$ ), or lung involvement (HR $0.78,95 \% \mathrm{CI} 0.47-1.17, \mathrm{p}=0.2288$ ) were not statistically significant (Figure 2A). However it is worth mentioning that $55 \%$ of patients without GI cGvHD discontinued IST, while $28 \%$ achieved this goal with mild GI GvHD, 26\% with moderate and $8 \%$ with severe. The same pattern was observed for lung GvHD: 47\% discontinued systemic IST without lung involvement and $25 \%$ with mild bronchiolitis obliterans (BO), $29 \%$ with moderate and only $10 \%$ with severe. Absence of significance in the multivariate analysis may be partially explained by certain overlap of these variables with overall severity of cGvHD. Among patients with moderate disease $56 \%$ discontinued IST, but with severe disease - only $25 \%$. At the end of the follow up patients with CR discontinued IST in $91 \%$ of cases, with mild cGvHD in $53 \%$ of cases, with moderate in $24 \%$ of cases and with severe in $2 \%$ of cases.

The analysis of NRM demonstrated that the major factors with impact on 5-year NRM were severe form of cGvHD ( $32 \%$ vs $13 \%, \mathrm{p}=0.0050$ ), discontinuation of systemic IST ( $2 \%$ vs $42 \%, \mathrm{p}<0.0001)$ and surprisingly steroid-free firstline therapy ( $8 \%$ vs $32 \%, \mathrm{p}=0.0006)$. Although administration of second-line regimens were not statistically significant in this data set (NRM 20\% vs 27\%, $\mathrm{p}=0.7092$ ) (Fig. 3), it was forced in the subsequent multivariate analysis due to significant literature data on increased mortality in steroidrefractory GvHD.

In the multivariate analysis it was demonstrated that the initial severity of cGvHD did not influenced the NRM (HR 1.70, 95\%CI 0.80-3.97, $\mathrm{p}=0.1959$ ), while early discontinuation of IST (HR 0.03, 95\%CI 0.01-0.15, p=0.0005), steroid-free starting therapy ( $\mathrm{HR} 0.25,95 \% \mathrm{CI} \quad 0.08-0.58, \mathrm{p}=0.0035)$ and use of second-line therapy (HR 0.49, 95\%CI 0.25-0.96, $\mathrm{p}=0.0322$ ) were protective against NRM (Fig. 2B). Since it was a non-randomized study patients with steroid-free starting therapy more often had moderate disease compared to patients in the steroids group ( $41 \%$ vs $66 \%, \mathrm{p}=0.0011$ ). The same is true for additional cGvHD therapy: 54\% received it in the severe group, while only $20 \%$ received it in the moderate $c \mathrm{GvHD}$ group.

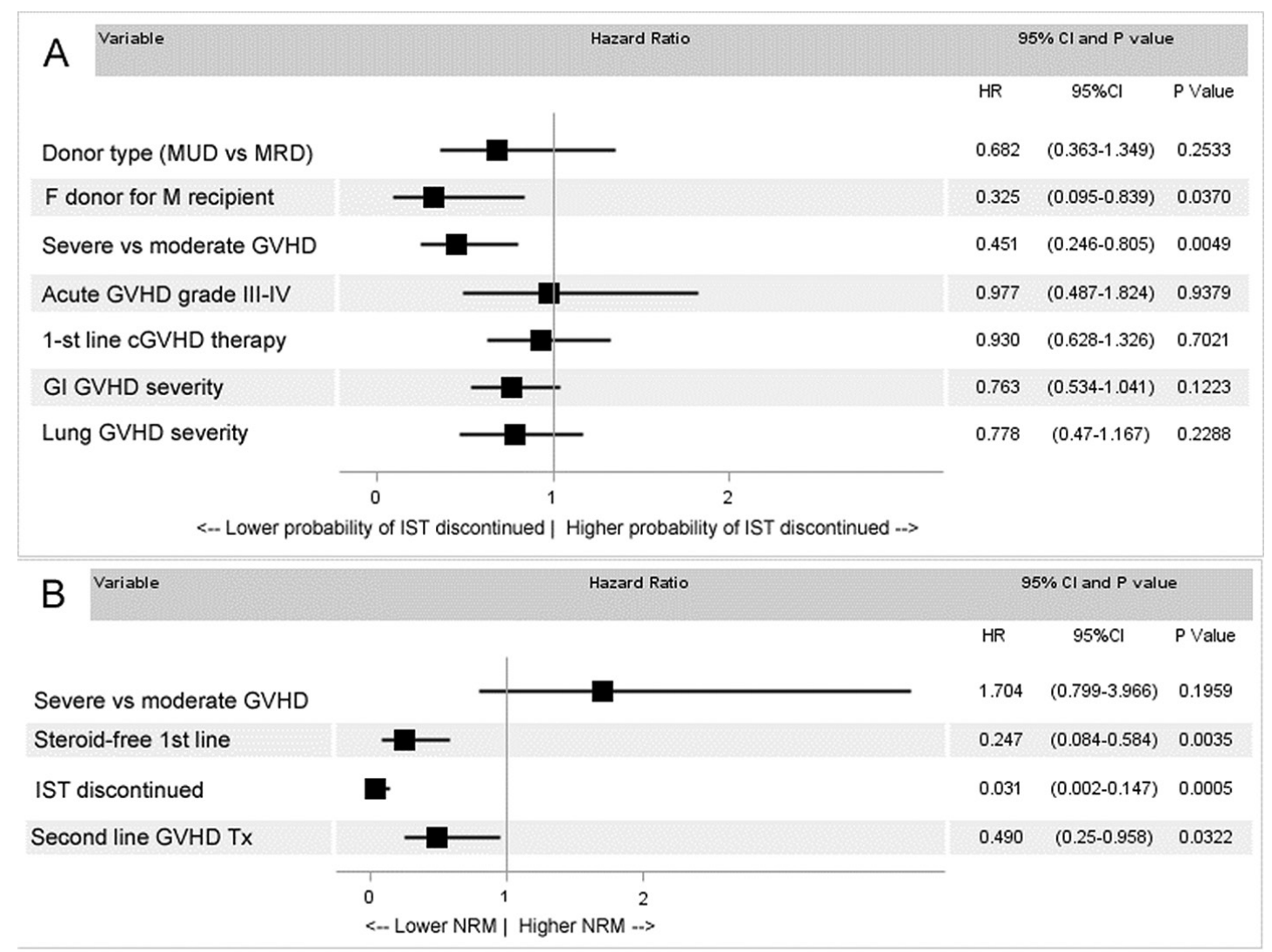

Figure 2. (A) Multivariate analysis of predictors for successful IST discontinuation. (B) Multivariate analysis of predictors for non-relapse mortality

$M U D=$ matched unrelated donor, $M R D=$ matched related donor, GI=gastrointestinal. IST=immunosuppressive treatment. Factors with significance $<0.1$ in the univariate analysis were included. 

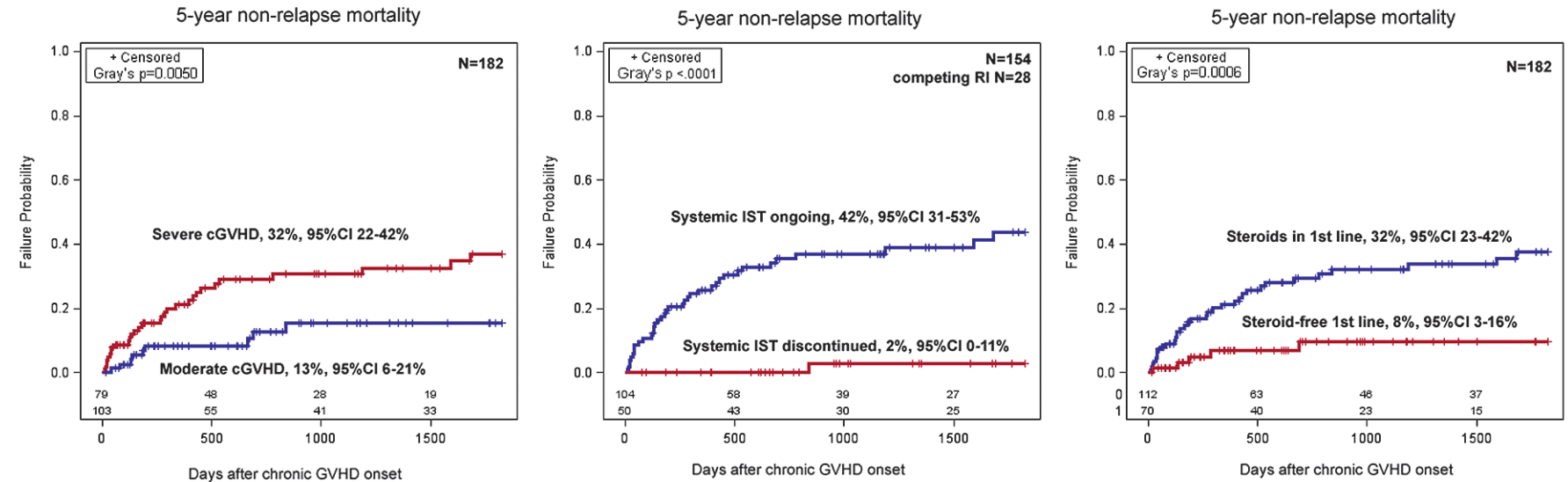

Figure 3. Major predictors of non-relapse mortality

\section{Discussion}

This retrospective analysis of the large single center-cohort is not in line with several previous studies. The initial studies of cGvHD treatment identified prednisone as an optimal therapy among the existing at that time immunosuppressive agents $[10,11]$. Many clinics even do not use CNIs in combination with steroids for the treatment, given the comparable response rate [14]. All the subsequent studies demonstrated that addition of thalidomide [13], or MMF [21], or ECP [22] in the first line of therapy did not improve response or survival. In our single-center study of patients with cGvHD many did not receive first line steroids. Partly, this was due to the single-agent PTCY prophylaxis protocol involving first line CsA for both acute and chronic GvHD, but also due national peculiarities of healthcare when a patient cannot easily travel to the transplant center and CNIs had to be introduced during distant consultations, while treatment with steroids were saved only for patients who could be admitted to the outpatient care. Secondly, there was an internal policy of faster steroid tapper after introduction of second line treatment than in the majority of centers [23]. Hence, if the patient did not show the signs of the flair he usually completely discontinued steroids within a month and continued only second line treatment, while the standard policy is to continue steroids until response. These differences in the internal policies led to several interesting discoveries.

First, patients initially treated without steroids had significantly reduced NRM. Although it is not well documented in the literature, but the majority of early deaths in chronic GvHD patients occur not due to cGvHD clinical manifestations, but due to recurrent infections [24]. Hence, the modality of immunosuppressive therapy should focus on minimal increase in the rate of infectious complications while providing at least minimal continuous GvHD improvement. This goes in line with recent single cell sequencing studies demonstrating that variation in $\mathrm{CGvHD}$ manifestation is due to the mixture of alloreactive graft-derived cells and de novo T-cells generated in thymus. Exhaustion of these clones is associated with cGvHD amelioration or resolution $[25,26]$. Now there is not enough data to support that exhaustion and elimination of GvHD-related T-cells is a consequence of IST. This might be as well the result of restored process of negative $\mathrm{T}$-cell cell selection in the thymus [27]. This study proposes the idea that minimally effective immunosuppression should be used.

At the time R. Storb et al. compared the efficacy of various IST with prednisone the choice of agents was limited to azathioprine, methotrexate and cyclophosphamide. Now we have several effective therapy options for cGVHD, including ECP [28], JAK inhibitors [18], BTK inhibitors [17]. All of them were used either as early therapeutic intervention in the first or second lines of therapy in this study in a small proportion of patients. None of these agents were previously randomized against steroids but rather randomized on top of steroids. Second line therapy with kinase inhibitors demonstrated excellent survival, so moving this agents in the first line might reduce infection-related NRM [17, 19, 29]. Despite this was not a randomized study and steroid-free first line therapy group had less patients with severe $\mathrm{cGvHD}$, at least these results warrant randomized studies of novel therapies against steroids, but not with steroids.

Although it was demonstrated previously that patients with improvement in cGvHD manifestations have better survival compared to patients without improvement [30], this study demonstrated how long the IST should continue and when it should be stopped. The ideal situation is reaching CR or mild manifestations of cGvHD when systemic IST could be stopped and GvHD controlled by topical therapy. A quarter of patients with formal moderate disease can also stop systemic IST without a flare. Usually, these are lung GvHD patients who may never restore the lung capacity to normal, or patients with eye involvement in whom it will be controlled with topical therapy. Still there is a problem with patients who still have severe disease after several years of therapy. Despite they will have higher mortality than patients with GvHD resolution, in this study we demonstrated that they may benefit in terms of NRM from early intervention with second-line therapies or using them in the first line. Also prospective trials are required to confirm these observations. The long-term results of this approach is unknown, however we know that prolonged use of steroids is associated with dismal prognosis [6].

\section{Financial Disclosure Statement}

The authors have nothing to disclaim. 


\section{Acknowledgements}

The authors declare no conflicts of interest.

\section{References}

1. Storb R, Deeg HJ, Pepe M, Appelbaum F, Anasetti C, Beatty P, Bensinger W, Berenson R, Buckner CD, Clift R, et al. Methotrexate and cyclosporine versus cyclosporine alone for prophylaxis of graft-versus-host disease in patients given HLA-identical marrow grafts for leukemia: long-term follow-up of a controlled trial. Blood. 1989;73(6):1729-1734. PMID: 2653461.

2. Bacigalupo A, Lamparelli T, Bruzzi P, Guidi S, Alessandrino PE, di Bartolomeo P, Oneto R, Bruno B, Barbanti M, Sacchi N, Van Lint MT, Bosi A. Antithymocyte globulin for graft-versus-host disease prophylaxis in transplants from unrelated donors: 2 randomized studies from Gruppo Italiano Trapianti Midollo Osseo (GITMO). Blood. 2001;98(10):2942-2947.

3. Maschan M, Shelikhova L, Ilushina M, Kurnikova E, Boyakova E, Balashov D, Persiantseva M, Skvortsova Y, Laberko A, Muzalevskii Y, et al. TCR-alpha/beta and CD19 depletion and treosulfan-based conditioning regimen in unrelated and haploidentical transplantation in children with acute myeloid leukemia. Bone Marrow Transplant. 2016;51(5):668-674.

4. Ciurea SO, Mulanovich V, Saliba RM, Bayraktar UD, Jiang Y, Bassett R, Wang SA, Konopleva M, Fernandez-Vina $\mathrm{M}$, Montes $\mathrm{N}$, et al. Improved early outcomes using a $\mathrm{T}$ cell replete graft compared with $\mathrm{T}$ cell depleted haploidentical hematopoietic stem cell transplantation. Biol Blood Marrow Transplant. 2012;18(12):1835-1844.

5. Stern M, de Wreede LC, Brand R, van Biezen A, Dreger P, Mohty M, de Witte TM, Kröger N, Ruutu T. Sensitivity of hematological malignancies to graft-versus-host effects: an EBMT megafile analysis. Leukemia. 2014;28(11):2235-2240.

6. 6. Ruutu T, Nihtinen A, Niittyvuopio R, Juvonen E, Volin L. A randomized study of cyclosporine and methotrexate with or without methylprednisolone for the prevention of graft-versus-host disease: Improved long-term survival with triple prophylaxis. Cancer. 2018;124(4):727-733.

7. Inamoto Y, Pidala J, Chai X, Kurland BF, Weisdorf D, Flowers ME, Palmer J, Arai S, Jacobsohn D, Cutler C, Jagasia M, Goldberg JD, Martin PJ, Pavletic SZ, Vogelsang GB, Lee SJ, Carpenter PA; Chronic GVHD Consortium. Assessment of joint and fascia manifestations in chronic graft-versushost disease. Arthritis Rheumatol. 2014;66(4):1044-1052.

8. Glezerman IG, Jhaveri KD, Watson TH, Edwards AM, Papadopoulos EB, Young JW, Flombaum CD, Jakubowski AA. Chronic kidney disease, thrombotic microangiopathy, and hypertension following $\mathrm{T}$ cell-depleted hematopoietic stem cell transplantation. Biol Blood Marrow Transplant. 2010;16(7):976-984.

9. Worel N, Biener D, Kalhs P, Mitterbauer M, Keil F, Schulenburg A, Höcker P, Dieckmann K, Fischer G, Rosenmayr A, et al. Long-term outcome and quality of life of patients who are alive and in complete remission more than two years af- ter allogeneic and syngeneic stem cell transplantation. Bone Marrow Transplant. 2002;30(9):619-626.

10. Sullivan KM, Shulman HM, Storb R, Weiden PL, Witherspoon RP, McDonald GB, Schubert MM, Atkinson K, Thomas ED. Chronic graft-versus-host disease in 52 patients: adverse natural course and successful treatment with combination immunosuppression. Blood. 1981;57(2):267-276. PMID: 7004534.

11. Sullivan KM, Witherspoon RP, Storb R, Deeg HJ, Dahlberg S, Sanders JE, Appelbaum FR, Doney KC, Weiden P, Anasetti C, et al. Alternating-day cyclosporine and prednisone for treatment of high-risk chronic graft-v-host disease. Blood. 1988;72(2):555-561.

12. Martin PJ, Storer BE, Rowley SD, Flowers ME, Lee SJ, Carpenter PA, Wingard JR, Shaughnessy PJ, DeVetten MP, Jagasia M, et al. Evaluation of mycophenolate mofetil for initial treatment of chronic graft-versus-host disease. Blood. 2009;113(21):5074-5082.

13. Koc S, Leisenring W, Flowers ME, Anasetti C, Deeg HJ, Nash RA, Sanders JE, Witherspoon RP, Appelbaum FR, Storb R, Martin PJ. Thalidomide for treatment of patients with chronic graft-versus-host disease. Blood. 2000;96(12):39953996.

14. Koc S, Leisenring W, Flowers ME, Anasetti C, Deeg HJ, Nash RA, Sanders JE, Witherspoon RP, Storb R, Appelbaum FR, Martin PJ. Therapy for chronic graft-versus-host disease: a randomized trial comparing cyclosporine plus prednisone versus prednisone alone. Blood. 2002;100(1):48-51.

15. Ayuk F, Veit R, Zabelina T, Bussmann L, Christopeit M, Alchalby H, Wolschke C, Lellek H, Bacher U, Zander AR, Kröger N. Prognostic factors for survival of patients with newly diagnosed chronic GvHD according to NIH criteria. Ann Hematol. 2015;94(10):1727-1732.

16. Pavletic SZ, Smith LM, Bishop MR, Lynch JC, Tarantolo SR, Vose JM, Bierman PJ, Hadi A, Armitage JO, Kessinger A. Prognostic factors of chronic graft-versus-host disease after allogeneic blood stem-cell transplantation. Am J Hematol. 2005;78(4):265-274.

17. Miklos D, Cutler CS, Arora M, Waller EK, Jagasia M, Pusic I, Flowers ME, Logan AC, Nakamura R, Blazar BR, et al. Ibrutinib for chronic graft-versus-host disease after failure of prior therapy. Blood. 2017;130(21):2243-2250. doi: 10.1182/ blood-2017-07-793786.

18. Zeiser R, Burchert A, Lengerke C, Verbeek M, Maas-Bauer K, Metzelder SK, Spoerl S, Ditschkowski M, Ecsedi M, Sockel K, Ayuk F, et al. Ruxolitinib in corticosteroid-refractory graft-versus-host disease after allogeneic stem cell transplantation: a multicenter survey. Leukemia. 2015;29(10):2062-2068.

19. Jagasia MH, Greinix HT, Arora M, Williams KM, Wolff D, Cowen EW, Palmer J, Weisdorf D, Treister NS, Cheng GS, et al. National Institutes of Health Consensus Development Project on criteria for clinical trials in chronic graft-versus-host disease: I. The 2014 Diagnosis and Staging Working Group report. Biol Blood Marrow Transplant. 2015; 21(3):389-401.e1. 
20. Pavletic SZ, Martin P, Lee SJ, Mitchell S, Jacobsohn D, Cowen EW et al. Measuring therapeutic response in chronic graft-versus-host disease: National Institutes of Health Consensus Development Project on criteria for clinical trials in chronic graft-versus-host disease: IV. Response Criteria Working Group report. Biol Blood Marrow Transplant 2006; 12: 252-266.

21. Martin PJ, Storer BE, Rowley SD, Flowers ME, Lee SJ, Carpenter PA, Wingard JR, Shaughnessy PJ, DeVetten MP, Jagasia M, et al. Evaluation of mycophenolate mofetil for initial treatment of chronic graft-versus-host disease. Blood. 2009; 113(21):5074-5082.

22. Jagasia M, Scheid C, Socié G, Ayuk FA, Tischer J, Donato ML, Bátai Á, Chen H, Chen SC, Chin T, et al. Randomized controlled study of ECP with methoxsalen as first-line treatment of patients with moderate to severe cGVHD. Blood Adv. 2019;3(14):2218-2229.

23. Sarantopoulos S, Cardones AR, Sullivan KM. How I treat refractory chronic graft-versus-host disease. Blood. 2019;133(11):1191-1200.

24. Wingard JR, Majhail NS, Brazauskas R, Wang Z, Sobocinski KA, Jacobsohn D, Sorror ML, Horowitz MM, Bolwell B, Rizzo JD, Socié G. Long-term survival and late deaths after allogeneic hematopoietic cell transplantation. J Clin Oncol. 2011;29(16):2230-2239.

25. Balakrishnan A, Gloude N, Sasik R, Ball ED, Morris GP. Proinflammatory dual receptor T cells in chronic graft-versus-host disease. Biol Blood Marrow Transplant. 2017;23(11):1852-1860.

26. Kosugi-Kanaya M, Ueha S, Abe J, et al. Long-lasting graft-derived donor $\mathrm{T}$ cells contribute to the pathogenesis of chronic graft-versus-host disease in mice. Front Immunol. 2017;8:1842. doi:10.3389/fimmu.2017.01842.

27. Klein L, Robey EA, Hsieh CS. Central CD4+ T cell tolerance: deletion versus regulatory $\mathrm{T}$ cell differentiation. Nat Rev Immunol. 2019;19(1):7-18.

28. Greinix HT, Worel N, Just U, Knobler R. Extracorporeal photopheresis in acute and chronic graft-versus-host disease. Transfus Apher Sci. 2014;50(3):349-357.

29. Escamilla Gómez V, García-Gutiérrez V, López Corral L, García Cadenas I, Pérez Martínez A, Márquez Malaver FJ, Caballero-Velázquez T, González Sierra PA, Viguria Alegría MC, Parra Salinas IM, et al.; Grupo Español de Trasplante Hematopoyético (GETH). Ruxolitinib in refractory acute and chronic graft-versus-host disease: a multicenter survey study. Bone Marrow Transplant. 2020;55(3):641-648.

30. Murata M, Nakasone H, Kanda J, Nakane T, Furukawa T, Fukuda T, Mori T, Taniguchi S, Eto T, Ohashi K, et al. Clinical factors predicting the response of acute graft-versus-host disease to corticosteroid therapy: an analysis from the GVHD Working Group of the Japan Society for Hematopoietic Cell Transplantation. Biol Blood Marrow Transplant. 2013;19(8):1183-1189. 


\title{
Долгосрочные цели терапии хронической реакции «трансплантат против хозяина» после аллогенной совместимой трансплантации гемопоэтических стволовых клеток
}

\author{
Иван С. Моисеев, Анна А. Доценко, Анна Г. Смирнова, Юлия Ю. Власова, Елена В. Морозова, \\ Сергей Н. Бондаренко, Борис В. Афанасьев \\ НИИ детской онкологии, гематологии и трансплантологии им. Р. М. Горбачевой, Первый Санкт-Петербургский \\ государственный медицинский университет им. акад. И. П. Павлова, Санкт-Петербург, Россия
}

\section{Резюме}

Хроническая реакция «трансплантат против хозяина» (хрРТПХ) является частым осложнением аллогенной трансплантации гемопоэтических стволовых клеток. Частота развития этого осложнения колеблется от $10 \%$ до $80 \%$ в зависимости от типа профилактики, типа донора и других факторов риска. Хотя хрРТПХ ассоциируется со сниженным риском рецидива, персистенция клинических симптомов связана с долгосрочной летальностью, частыми госпитализациями и инвалидностью. Несмотря на то, что существуют четкие критерии эффективности для клинических испытаний новых препаратов, определение тактики в клинической практике должно включать и долгосрочные цели, как при всех аутоиммунных заболеваниях. Пока нет единого мнения в отношении этих целей терапии. Анализируя результаты терапии хрРТПХ в большой когорте пациентов в рамках одноцентрового исследования, мы попытались сосредоточиться на предикторах долгосрочного прогноза и их связи с терапией.

\section{Пациенты и методы}

В исследование были включены 182 пациента с средней тяжестью и тяжелой хрРТПХ. Большинству пациентов была проведена аллогенная трансплантация по поводу злокачественных заболеваний, у 49\% была тяжелая форма хрРТПХ, у 51\% - проявления средней степени тяжести. Среднее время наблюдения составило 52 месяца. Помимо первой линии, 39,56\% пациентов требовали дополнительного лечения.

\section{Результаты}

Через пять лет кумулятивная частота полных ремиссии составила 16,9\% (95\% ДИ 10,5-24,7\%), а частота прекращения иммуносупрессивной терапии (ИСТ) без обострения РТПХ составила 51,2\% (95\% ДИ 40,0-61,2\%). Основными предикторами отмены ИСТ были общая тяжесть хрРТПХ (HR 0,45, 95\% ДИ 0,25-0,84, $\mathrm{p}=0,0049)$ и женщина донор для реципиента мужчины (HR 0,33, 95\% CI 0,25-0,81, p=0,0370). Анализ частоты летальности без рецидива (ЛБР) показал, что прекращение ИСТ было основным предиктором ЛБР (2\% против 42\%, HR 0,03, 95\% CI 0,01-0,15, p=0,0005). В конце периода наблюдения пациенты с полным ответом прекратили ИСТ в 91\% случаев, с легкой формой РТПХ в 53\% случаев, со средней тяжести в $24 \%$ случаев и с тяжелой в $2 \%$ случаев. Другими значимыми факторами для ЛБР были начало терапии без стероидов (HR 0,25, 95\% ДИ $0,08-0,58, \mathrm{p}=0,0035)$ и раннее использование терапии второй линии (HR 0,49, 95\% CI 0,25-0,96, p=0,0322).

\section{Выводы}

Исследование продемонстрировало, что прекращение системной терапии ИСТ без обострения хронической РТПХ должно быть основной целью терапии. Кроме того, исследование указывает на обоснованность рандомизированных исследований новых методов второй линии не с глюкокортикостероидами в первой линии, а против них.

\section{Ключевые слова}

Хроническая реакция трансплантат против хозяина, терапия, долгосрочные результаты, цели терапии. 